\title{
MENGEMBANGKAN KAPASITAS GURU \\ DALAM MENINGKATKAN MOTIVASI BELAJAR SISWA \\ (PENDAMPINGAN DI MI AL HIDAYAH MARGOREJO SURABAYA)
}

\author{
Lailatu Zahroh \\ Aktivitas Muslimat Kota Surabaya \\ Lailatu.zahroh@yahoo.com \\ Lailatul Choiriyah \\ Mahasiswa PAI STAI Taruna Surabaya \\ Choirlaila24@gmail.com
}

\begin{abstract}
Abstrac : Capacity building is a process that occurs within the community itself. Outsiders cannot develop people, organizations, or communities, but it is the people, organizations or communities themselves who can develop themselves. Outsiders can only support by facilitating the process to accelerate their development, and help find access to the resources and inputs needed .Currently, improving the quality of learning is the dream of all teachers. The existence of an active role from all components will realize learning that is truly quality and also of high quality. The quality of learning can be realized and achieved when teachers are able to, among others, boost students' learning motivation. Motivation is a psychological condition that encourages someone to do something. Ibtidaiyah madrasas in the city of Surabaya, the majority of their learning quality is still far from expectations; and this is due to the low capacity of teachers. Thus, mentoring at MI Al Hidayah Margorejo Surabaya to develop teacher capacity in increasing students' learning motivation is urgent and significant in order to equip them to be later applied in learning activities for the convenience of achieving competence for students. This assistance can contribute in the form of developing teacher capacity in increasing student learning motivation at MI Al Hidayah Margorejo Surabaya.
\end{abstract}

Keywords: Teacher Capacity, Learning Motivation

\section{Pendahuluan}

Keberhasilan pendidikan tidak bisa terlepas dari pembelajaran. Sementara itu, pembelajaran merupakan hal yang tidak terpisahkan dari proses belajar. Dalam setiap kegiatan pembelajaran pasti ada proses belajar didalamnya. Proses belajar inilah yang menuntut seseorang untuk menjadi yang terbaik, berprestasi, dan dikenal banyak orang ${ }^{1}$. Pembelajaran adalah suatu kombinasi yang tersusun atas unsur-unsur manusiawi, material, fasilitas, perlengkapan dan prosedur yang saling mempengaruhi untuk mencapai tujuan pembelajaran. Kegiatan pembelajaranakan mengakibatkan

\footnotetext{
${ }^{1}$ Aminatul Zahroh, Membangun Kualitas Pembelajaran melalui Dimensi Profesionalisme Guru, (Bandung: Yrama Widya, 2015), hlm 237
} 
siswa mempelajari sesuatu dengan cara yang lebih efektif dan efisien. Pembelajaran dikatakan efektif apabila dalam kegiatan pembelajaran guru dapat membelajarkan siswa dan memiliki pengaruh yang baik, atau bisa dikatakan bahwa pembelajaran tersebut memiliki feel yang baik sehingga dapat menuai keberhasilan. Pembelajaran efektif dapat digunakan untuk membentuk pengetahuan, sikap, keterampilan, serta pertumbuhan daya cipta siswa. Sementara itu, pembelajaran dapat dikatakan efisien, apabila dalam kegiatan pembelajaran guru dapat mendayagunakan rencana pembelajaran agar berjalan sesuai dengan tujuan yang telah dirumuskan, sehingga tidak membuang-buang waktu, tenaga, dan biaya. Dengan kata lain, waktu, tenaga, dan biaya dapat dimanfaatkan seefisien dan seefektif mungkin.

Penguatan kapasitas guru merupakan kunci penting untuk meningkatkan kualitas pembelajaran; salah satu masalah yang dihadapi dunia pendidikan kita saat ini, adalah masalah lemahnya kapasitas guru dalam meningkatkan motivasi belajar siswa . Terdapat perbedaan pendapat mengenai pengertian kapasitas, sebagian orang merujuk kepada pengertian dalam konteks kemampuan (pengetahuan, keterampilan). Sebagian lagi mengartikan kapasitas dalam konteks yang lebih luas termasuk didalamnya soal sikap dan perilaku. Sebagian ilmuwan juga melihat pengembangan kapasitas sebagai capacity development atau capacity strengthening, mengisyaratkan suatu prakarsa pada pengembangan kemampuan yang sudah ada (existing capacity). Sementara yang lain lebih merujuk pada constructingcapacity sebagai proses kreatif membangun kapasitas yang belum nampak (not yet exist) ${ }^{2}$. Dari beberapa pendapat diatas dapat disimpulkan bahwa kapasitas adalah kemampuan yang meliputi pengetahuan, keterampilan, sikap dan perilaku. Jadi jelaslah bahwa peningkatan kapasitas bagi seorang guru itu sangat urgen sekali, karena bila kapasitas guru rendah maka akibatnya dalam kegiatan pembelajaran diantaranya: (1) siswa kurang didorong untuk mengembangkan kemampuan berfikir, (2) kegiatan pembelajaran didalam kelas diarahkan kepada kemampuan anak untuk menghafalkan informasi, (3) otak anak

\footnotetext{
${ }^{2}$ Riyadi Soeprapto, The Capacity Building for Local Government toward Good Governance (Word Bank,
} 
dipaksa untuk mengingat dan menimbun berbagai informasi tanpa dituntut untuk memahami informasi yang diingatnya itu untuk menghubungkannya dengan kehidupan sehari-hari. Akibatnya ketika siswa lulus dari sekolah, mereka pintar secara teoritis tetapi mereka miskin aplikasi ${ }^{3}$. Peningkatan kapasitas merupakan suatu proses yang terjadi didalam komunitas itu sendiri. Pihak luar tidak dapat mengembangkan orang-orang, organisasi, atau masyarakat, namun orang-orang, organisasi atau masyarakat itu sendirilah yang dapat mengembangkan diri mereka. Pihak luar hanya dapat mendukung dengan cara memfasilitasi proses untuk mempercepat perkembangan mereka, serta membantu menemukan akses terhadap sumber daya dan input yang dibutuhkan ${ }^{4}$.

Pembelajaran tidak akan berjalan secara efektif apabila guru tidak bisa mengkondisikan semua komponen pembelajaran dengan baik dan tepat. Dalam konteks ini, peran dan tugas guru dalam interaksi edukatif sangat membantu kelancaran proses pembelajaran. Apalagi dengan adanya inovasi yang dihadirkan guru pada setiap pertemuan. Selain inovasi, guru juga dituntut untuk memiliki kreativitas dalam menjalankan setiap roda pembelajaran. Dari hal inilah akan dicapai tujuan pembelajaran. Tujuan pembelajaran itu sendiri pada dasarnya bukan hanya mengubah perilaku siswa, melainkan lebih untuk membentuk fondasi karakter dan membentuk sikap mental professional serta berintelektual tinggi yang berorientasi pada global mindset. Untuk itulah diupayakan peningkatan kualitas pembelajaran.

Saat ini, peningkatan kualitas pembelajaran menjadi dambaan semua guru. Adanya peran aktif dari seluruh komponen akan mewujudkan pembelajaran yang memang benar-benar bermutu dan juga berkualitas. Kualitas pembelajaran bisa terwujud dan tercapai manakala guru mampu diantaranya mendongkrak motivasi belajar siswa

Motivasi ialah kondisi psikologis yang mendorong seseorang untuk melakukan sesuatu. Motivasi untuk belajar ialah kondisi psikologis

\footnotetext{
${ }^{3}$ Wina Sanjaya, 2006, Strategi Pembelajaran Berorientasi Standar Proses Pendidikann, Jakarta,KencanaPrenada M, hlm 1

4 Lailatu Zahroh, dkk, Mengembangkan Kapasitas Guru dengan Media Pembelajaran ICT, (Surabaya:Jaudar Press, 2016), hlm 16
} 
yang mendorong seseorang untuk belajar. Ngalim Purwanto menyatakan bahwa penemuan-penemuan penelitian menunjukkan bahwa hasil belajar pada umumnya meningkat jika motivasi untuk belajar meningkat ${ }^{5}$. M.Dalyono menyatakan bahwa kuat lemahnya motivasi belajar seseorang turut mempengaruhi keberhasilan belajar, oleh karena itu motivasi belajar perlu diusahakan terutama yang berasal dari dalam diri (motivasi intrinsik) dengan cara senantiasa memikirkan masa depan yang penuh tantangan dan harus dihadapi untuk mencapai cita-cita. Senantiasa memasang tekat bulat dan selalu optimis bahwa cita-cita dapat dicapai dengan belajar ${ }^{6}$.

Madrasah-madrasah Ibtidaiyah di Kota Surabaya mayoritas kualitas pembelajarannya masih jauh dari harapan; dan ini disebabkan karena kapasitas guru yang masih rendah. Sebagaimana yang disampaikan oleh Bapak HM.Jalaluddin: "Pembelajaran akan berjalan secara efektif apabila guru bisa mengondisikan semua komponen pembelajaran dengan baik dan tepat; tapi masih banyak guru Madrasah Ibtidaiyah yang kurang pandai membangkitkan motivasi belajar siswa, kurang mampu mendayagunakan sumber belajar, kurang mampu mengembangkan kreativitas siswa kurang mampu mengembangkan kecerdasan emosi siswa dan kurang mampu mendisiplinkan siswa. Padahal kalau semua ini bisa dilakukan guru maka kualitas pembelajaran akan terwujud secara sempurna. Ini masih menjadi impian" "Tependapat dengan Kepala LP Ma'arif Kota Surabaya, Bapak Reza selaku Kepala Sekolah MI Al Hidayah Margorejo Surabaya menyampaikan :

"Benar apa yang dikatakan Ketua LP Ma'arif Jawa Timur, di MI Al Hidayah ini di samping seperti yang disampaikan beliau, malahan saya menambahkan banyak guru yang kurang mampu mengembangkan kecerdasan emosi siswa dan kurang mampu mendisiplinkan siswa.Dan akibat dari kapasitas guru yang kurang mumpuni sehingga kualitas pembelajaran sangat rendah, sehingga prestasi yang diraih oleh MI Al Hidayah ini minim baik itu prestasi akademik maupun prestasi non akademik. Efeknya madrasah ini sangat dipandang sebelah mata oleh para

\footnotetext{
${ }^{5}$ Ngalim Purwanto,Psikologi Pendidikan, cet X, (Bandung: Remaja Rosdakarya, 2005), h/m 6

${ }^{6}$ M.Dalyono, Psikologi Pendidikan, Cet.I, Jakarta, Rineka Cipta, 2007), hlm 57

${ }^{7}$ M.Dalyono, Psikologi Pendidikan, Cet.I, Jakarta, Rineka Cipta, 2007), hlm 57
} 
calon wali siswa, sehingga jumlah siswa sangat sedikit"8

Madrasah Ibtidaiyah Al Hidayah Margorejo yang memiliki luas tanah $132 \mathrm{M}^{2}$ beralamatkan di J1. Margorejo Masjid No. 3E Surabaya secara resmi mendapatkan surat izin kelembagaan dari kantor Departemen Agama No. Lm/3/052/A/1978 Tanggal 20-3-1978, pada tahun pelajaran 2020-2021 ini memiliki jumlah siswa Kelas I - VI sebanyak 68 siswa, dengan perincian kelas I ada 5 siswa, Kelas II ada 13 siswa, Kelas III ada 13 siswa, Kelas IV ada 6 siswa, kelas V ada 17 siswa dan Kelas VI ada 14 siswa9.

Madrasah Ibtidaiyah Al Hidayah Margorejo Surabaya sejak awal berdirinya belum banyak mendapatkan prestasi baik akademik maupun akademik, hal ini disebabkan diantaranya kapasitas guru rendah dalam meningkatkan motivasi belajar siswa, sehingga madrasah ini sangat dipandang sebelah mata oleh para calon wali siswa. Mereka lebih suka menyekolahkan anak-anak mereka ke SDN Margorejo I, SDN Margorejo II, SDN Margorejo III, SDN Margorejo IV, SDN Margorejo V, SDN Margorejo VI, SDN Margorejo VII dan SDN Margorejo VIII.

Dengan demikian, pendampingan di MI Al Hidayah Margorejo Surabaya untuk mengembangkan kapasitas guru dalam meningkatkan motivasi belajar siswa urgen dan signifikan dilakukan demi membekali mereka untuk kemudian diterapkan dalam kegiatan pembelajaran demi kemudahan ketercapaian kompetensi bagi siswa. Pendampingan ini dapat memberikan kontribusi berupa berkembangnya kapasitas guru dalam meningkatkan motivasi belajar siswa di MI Al Hidayah Margorejo Surabaya.

\section{Pembahasan}

a. Tujuan

Pendampingan di MI Al Hidayah Margorejo Surabaya ini bertujuan:

1. Mengembangkan kapasitas guru MI Al Hidayah Margorejo Surabaya,

2. Meningkatkan motivasi belajar siswa di MI Al Hidayah Margorejo Surabaya b. Alasan Memilih Dampingan

\footnotetext{
${ }^{8}$ Hasil Wawancara dengan Bapak HM Djalaluddin, Ketua LP Ma'arif Kota Surabaya pada tanggal 12 Pebruari 2011

9 Hasil Wawancara dengan Bapak Moch. Reza Abady, S.Pd I, Kepala Sekolah MI Al Hidayah Margorejo 
Alasan memilih Madrasah Ibtidaiyah Al Hidayah Margorejo Surabaya sebagai subyek dampingan diantaranya karena sekolah ini sejak awal berdirinya belum banyak mendapatkan prestasi baik akademik maupun akademik, hal ini disebabkan diantaranya kapasitas guru rendah, sehingga madrasah ini sangat dipandang sebelah mata oleh para calon wali siswa. Mereka lebih suka menyekolahkan anakanak mereka ke SDN Margorejo I, SDN Margorejo II, SDN Margorejo III, SDN Margorejo IV, SDN Margorejo V, SDN Margorejo VI, SDN Margorejo VII dan SDN Margorejo VIII

c. Kondisi Subyek Dampingan

MI Al Hidayah Margorejo Surabaya yang peneliti jadikan subyek dampingan, saat ini jauh tertinggal dari sekolah-sekolah tingkat dasar yang ada di sekelilingnya baik dalam hal manajemen maupun prestasi. Sehingga seringkali dipandang sebelah mata oleh para orang tua yang memiliki anak usia masuk sekolah dasar. Apalagi dalam radius 1 - 1,5 KM MI Al Hidayah dikelilingi sekolah-sekolah yang bagus diantaranya SDN Margorejo I, SDN Margorejo III, SDN Margorejo IV, SDN Margorejo V, SDN Margorejo VI, SDN Margorejo VII dan SDN MargorejoVIII. Hal ini terlihat dari animo yang kurang dari masyarakat untuk menyekolahkan anaknya di MI Al Hidayah Margorejo Surabaya dan akhirnya jumlah siswa menurun dan juga prestasi yang belum pernah dicapai oleh anak-anak MI 1 Hidayah yang disebabkan kapasitas guru yang rendah dan lemahnya kualitas pembelajaran.

Dari hasil studi pendahuluan yang telah dilakukan oleh tim pendamping, maka dapat dideskripsikan kondisi sekolah dampingan sebagaimana berikut di bawah ini

\section{Tabel 1.1}

\section{Kondisi Sekolah Dampingan Saat Ini}

\begin{tabular}{|l|l|l|}
\hline \multicolumn{1}{|c|}{ Kondisi Guru } & $:$ & $\begin{array}{l}\text { Belum mampu membangkitkan motivasi belajar } \\
\text { siswa }\end{array}$ \\
\hline Kondisi Siswa & $:$ & Motivasi belajar siswa rendah \\
\hline $\begin{array}{l}\text { Kondisi } \\
\text { Pembelajaran }\end{array}$ & $:$ & $\begin{array}{l}\text { Kegiatan pembelajaran di MI Al Hidayah } \\
\text { Margorejo Surabaya sering berjalan secara } \\
\text { konvensional, dan kurang kreatif sehingga kualitas } \\
\text { pembelajarannya rendah dan ini berakibat pada }\end{array}$ \\
\hline
\end{tabular}




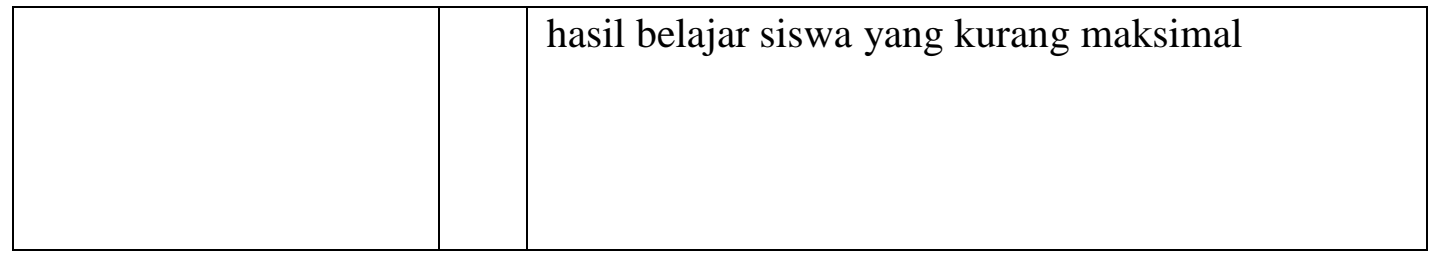

d. Out Put Pendampingan Yang Diharapkan

Berdasarkan hasil wawancara dan diskusi informal yang sudah dilakukan pendamping, kondisi yang diharapkan dari madrasah dampingan sebagaimana berikut:

Tabel 1.2

\section{Kondisi Sekolah Dampingan yang diharapkan}

\begin{tabular}{|c|c|c|}
\hline Kondisi Guru & ： & Mampu membangkitkan motivasi belajar siswa \\
\hline Kondisi Siswa & & Motivasi belajar siswa tinggi \\
\hline $\begin{array}{l}\text { Kondisi } \\
\text { Pembelaj } \\
\text { aran }\end{array}$ & & $\begin{array}{l}\text { Proses pembelajaran menjadi lebih efektif, efisien, serta } \\
\text { mendorong kreatifitas guru dan siswa sehingga kualitas } \\
\text { pembelajarannya tinggi dan ini } \\
\text { berakibat pada hasil belajar siswa yang baik }\end{array}$ \\
\hline
\end{tabular}

e. Strategi Yang Digunakan

Agar supaya kondisi yang menjadi harapan (expected target) dalam program pendampingan kali ini dapat dicapai secara maksimal, maka pihak pelaksana program mencanangkan beberapa strategi. Setidaknya ada beberapa faktor yang harus dilakukan dalam memfasilitasi suatu proses belajar yang melibatkan multipihak yang berkepentingan (multistakeholders), antara lain:

1. Program ini akan diarahkan kepada proses-proses interaksi untuk mengembangkan pemahaman tentang masalah yang dihadapi bersama dan opsi-opsi solusinya

2. Pendamping membantu mengembangkan pemahaman bersama tentang permasalahan dan solusinya melalui komunikasi dialogis.

3. Pendamping akan mendampingi proses-proses pengambilan keputusan bersama, bukan mendiktekan solusi atas suatu 
permasalahan.

4. Pendamping hanya sebatas memfasilitasi pengambilan keputusan secara partisipatif, yakni dengan menggunakan alat dan metode yang beragam untuk memenuhi kebutuhan belajar dari setiap pihak yang berkepentingan yang terlibat di dalam proses yang beragam pula.

Dengan memperhatikan beberapa faktor di atas yang merupakan cerminan fasilitasi pembelajaran sosial, maka setiap tindakan dalam program pendampingan ini tidak pernah terlepas dari hasil observasi pendahuluan ataupun pemetaan awal (preeliminary mapping). Dari assessment awal inilah dilakukan sebuah refleksi yang dilanjutkan dengan perencanaan aksi strategis secara bersama-sama sebelum dilanjutkan dengan sebuah tindakan nyata $^{10}$. Bahkan aksi ataupun tindakan yang telah dilakukan tidak dibiarkan usang tanpa arti, melainkan dievaluasi untuk direfleksi kembali dan di-follow-up-i dengan rencana aksi strategis yang lain dan berujung pada sebuah produk aksi yang baru. Demikian siklus ini terus diulang dalam proses pembelajaran social yang diterapkan dalam program pendampingan.

\section{f. Langkah-Langkah Dalam Pendampingan}

Adapun langkah-langkah strategis yang akan dilakukan dalam proses pelaksanaan program pendampingan ini dapat dijelaskan sebagaimana uraian di bawah ini:

1. Tahap Pendahuluan

Dari hasil studi pendahuluan diperoleh data bahwa problem praktis yang dihadapi komunitas dampingan di Madrasah Ibtidaiyah Al Hidayah Margorejo Surabaya adalah terkait lemahnya kapasitas guru dalam meningkatkan motivasi belajar siswa

a. Forum Group Discussion (FGD)

Kegiatan ini dilakukan untuk mengklarifikasi hasil temuan riset awal yaitu problema praktis yang dihadapi komunitas

${ }^{10}$ Djemari Mardapi, Metodologi Penelitian Kualitatif (Yogyakarta: Lemlit UNY, 2007). 
dampingan Madrasah Ibtidaiyah Al Hidayah Margorejo Surabaya adalah terkait rendahnya kapasitas guru dalam meningkatkan motivasi belajarsiswa.

b. Penyusunan Action Plan

Menyusun rancangan tindakan yang akan dilaksanakan. Setelah mengidentifikasi dan merumuskan permasalahan yang dihadapi, kemudian memutuskan pola perbaikan yang akan digunakan untuk meningkatkan kapasitas guru dalam meningkatkan motivasi belajar siswa. dengan rancangan tindakan yang akan dilaksanakan yaitu pendampingan

c. Pendampingan pengembangan kapasitas guru dalam meningkatkan motivasi belajar Pendampingan membangkitkan motivasi belajar siswa dengan mengembangkan kapasitas guru Madrasah Ibtidaiyah Al Hidayah Margorejo Surabaya

d. Aksi Pendampingan

Pendampingan di laksanakan di MI Al Hidayah Margorejo Surabaya

e. Refleksi $\longrightarrow$ Aksi Pendampingan $\longrightarrow$ Rekomendasi $\longrightarrow$ Aksi Lapangan $\longrightarrow$ Lahirnya Pengetahuan dan Keterampilan Baru

f. Penulisan dan Penyusunan Laporan Pendampingan

E. Pemilihan Subyek Dampingan

Alasan memilih Madrasah Ibtidaiyah Al Hidayah Margorejo Surabaya sebagai subyek dampingan diantaranya karena sekolah ini sejak awal berdirinya belum banyak mendapatkan prestasi baik akademik maupun akademik, hal ini disebabkan diantaranya kapasitas guru rendah, sehingga madrasah ini sangat dipandang sebelah mata oleh para calon wali siswa. Mereka lebih suka menyekolahkan anakanak mereka ke SDN Margorejo I, SDN Margorejo II, SDN Margorejo III, SDN Margorejo IV, SDN Margorejo V, SDN Margorejo VI, SDN Margorejo VII dan SDN Margorejo VIII

f. Hasil Dampak Perubahan

Sub ini menyajikan hasil yang dicapai setelah pelaksanaan pengabdian. Banyak hasil yang dicapai setelah pelaksanaan pengabdian 
berupa pendampingan guru dan tenaga kependidikan di MI Hidayah Margorejo Surabaya Tahun Pelajaran 2020-2021. Secara umum guruguru (peserta pendampingan) sebelumnya belum mampu meningkatkan motivasi belajar siswa; sesudah pendampingan guru dan tenaga kependidikan MI Al Hidayah Margorejo Surabaya mampu memotivasi siswa walaupun masih belum sampai pada tahap kemahiran.

Materi awal yang dilatihkan kepada peserta adalah tentang membangkitkan motivasi belajar siswa. Materi ini berisi seputar pentingnya siswa memiliki motivasi. Siswa akan berhasil dalam belajar, kalau pada dirinya ada keinginan (motivasi) unruk belajar. Keinginan atau dorongan untuk belajar inilah yang disebut dengan motivasi. Melalui motivasi, pembelajaran terus diupayakan untuk ditingkatkan. Motivasi merupakan salah satu faktor yang dapat meningkatkan kualitas pembelajaran, karena siswa akan belajar dengan sungguh-sungguh apabila memiliki motivasi yang tinggi. Motivasi adalah bagian terpenting dari keadaan pembelajaran (motivation is an essential condition of learning). Hasil belajar akan maksimal jika ada motivasi di dalamnya. Oleh karena itu, perlu meningkatkan motivasi belajar siswa, sehingga dapat mencapai tujuan dari pembelajaran.

Dalam materi "Membangkitkan Motivasi Belajar Siswa", peserta dikenalkan dan diarahkanuntuk dapat memahami dan memotivasi belajar siswanya. Perubahan positif pada peserta pendampingan diketahui melalui hasil pretes dan postes yang diberikan kepada peserta pendampingan guna mengetahui nilai efek serta perubahan yang terjadi pada peserta. 


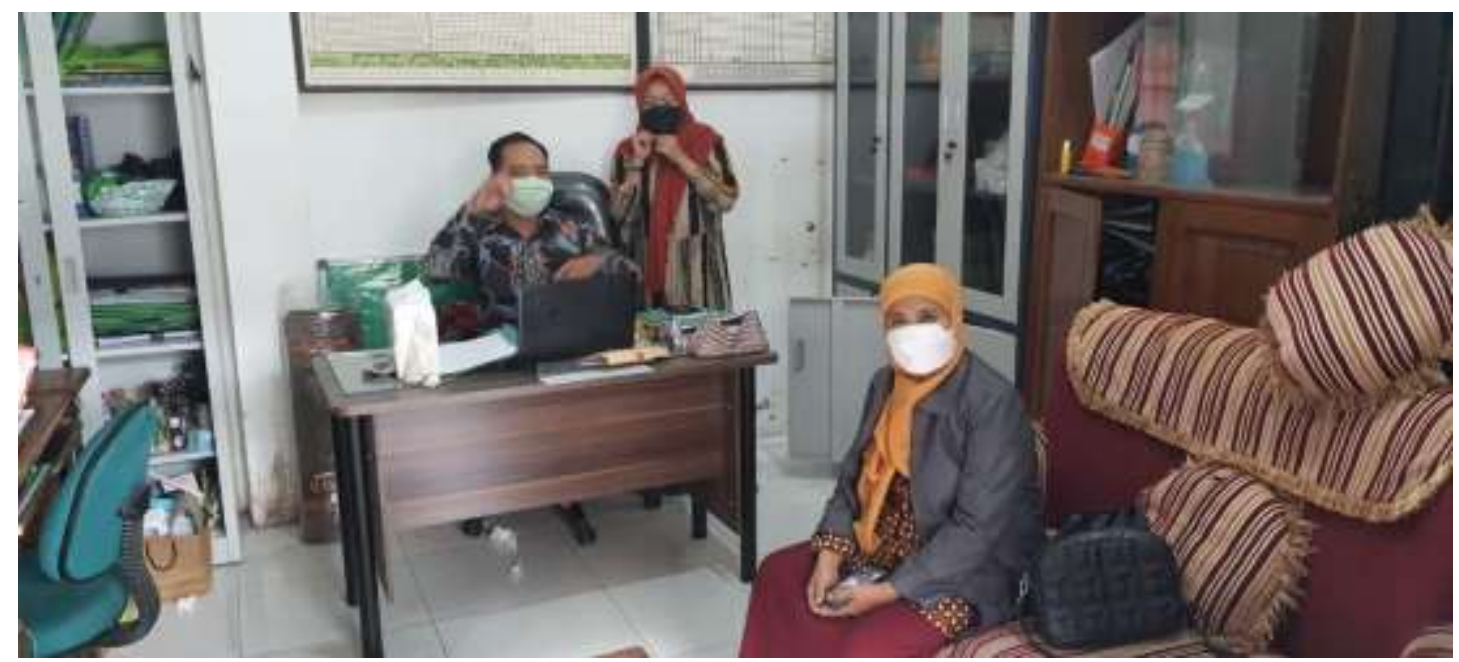

Gambar 1. Persiapan Pre-Test

Data pretes dan postes tentang "Membangkitkan Motivasi Belajar Siswa" dianalisis secara deskriptif dengan penyajian table dan dideskripsikan serta diambil kesimpulan melalui hasil rata- rata kemampuan peserta pada setiap materi pendampingan berdasarkan kriteria yang ditentukan. Penentuan kriteria mengacu pada rumus yang dikembangkan oleh Djemari Merdapi ${ }^{11}$ sebagai berikut:

Tabel 3.1

\section{Pedoman Penilaian Pretes Postes}

Materi "Membangkitkan Motivasi Belajar Siswa"

\begin{tabular}{|c|c|}
\hline Skor & Kategori \\
\hline $\mathrm{X}>3$ & Sangat Tinggi \\
\hline $3>\mathrm{X}>2,5$ & Tinggi \\
\hline $2,5>\mathrm{X}>2$ & Cukup \\
\hline $\mathrm{X}<2$ & Rendah \\
\hline
\end{tabular}

Hasil data Pretes materi "Membangkitkan Motivasi Belajar Siswa" dapat disajikan dandianalisis sebagai berikut:

\footnotetext{
${ }^{11}$ Djemari Mardabi, Tehnik Penyusunan Instrumen Tes dan Non tes (Yogyakarta: Rosda, 20018), hm 123
} 
Tabel 3.2

Data Hasil Pretes Materi "Membangkitkan

Motivasi Belajar Siswa"

\begin{tabular}{|c|c|c|c|c|c|c|c|c|c|c|c|c|c|}
\hline \multirow[t]{2}{*}{ NO } & \multirow[t]{2}{*}{ PESERTA } & \multicolumn{10}{|c|}{ Item Pretes } & \multirow[t]{2}{*}{$\mathbf{J}$} & \multirow[t]{2}{*}{$\mathbf{R}$} \\
\hline & & 1 & 2 & 3 & 4 & 5 & 6 & 7 & 8 & 9 & 10 & & \\
\hline 1 & Peserta 1 & 1 & 1 & 1 & 1 & 2 & 2 & 2 & 2 & 2 & 2 & 16 & 1,6 \\
\hline 2 & Peserta 2 & 1 & 2 & 1 & 1 & 2 & 2 & 1 & 2 & 1 & 2 & 15 & 1,5 \\
\hline 3 & Peserta 3 & 3 & 3 & 3 & 2 & 4 & 4 & 4 & 4 & 4 & 4 & 35 & 3,5 \\
\hline 4 & Peserta 4 & 1 & 1 & 1 & 1 & 2 & 1 & 1 & 1 & 1 & 1 & 11 & 1,1 \\
\hline 5 & Peserta 5 & 1 & 1 & 1 & 1 & 2 & 1 & 1 & 1 & 1 & 1 & 11 & 1,1 \\
\hline 6 & Peserta 6 & 2 & 1 & 1 & 1 & 1 & 1 & 1 & 2 & 1 & 2 & 13 & 1,3 \\
\hline 7 & Peserta 7 & 2 & 1 & 1 & 1 & 2 & 2 & 1 & 2 & 2 & 2 & 16 & 1,6 \\
\hline 8 & Peserta 8 & 1 & 1 & 1 & 1 & 1 & 1 & 1 & 1 & 1 & 1 & 10 & 1,0 \\
\hline 9 & Peserta 9 & 2 & 2 & 2 & 2 & 2 & 2 & 2 & 2 & 2 & 2 & 20 & 2,0 \\
\hline 10 & Peserta 10 & 1 & 1 & 1 & 1 & 4 & 4 & 2 & 2 & 2 & 2 & 20 & 2,0 \\
\hline 11 & Peserta 11 & 1 & 1 & 1 & 1 & 2 & 1 & 1 & 1 & 1 & 1 & 11 & 1,1 \\
\hline 12 & Peserta 12 & 1 & 1 & 1 & 1 & 2 & 1 & 1 & 1 & 1 & 1 & 11 & 1,1 \\
\hline 13 & Peserta 13 & 1 & 1 & 1 & 1 & 2 & 2 & 1 & 1 & 1 & 2 & 13 & 1,3 \\
\hline 14 & Peserta 14 & 2 & 2 & 2 & 2 & 2 & 2 & 2 & 2 & 2 & 2 & 19 & 1,9 \\
\hline 15 & Peserta 15 & 1 & 1 & 1 & 1 & 2 & 2 & 1 & 1 & 1 & 1 & 12 & 1,2 \\
\hline & & & & & & & & & & & & & 1,6 \\
\hline
\end{tabular}

Hasil Pretes Materi "Membangkitkan Motivasi Belajar Siswa" pada tabel diatas menunjukkan bahwa nilai rata-rata kemampuan peserta pendampingan adalah. 1,6 ; apabia dikonsultasikan pada kriteria sebagaimana table skor penilaian, maka nilai tersebut berada pada kategori Rendah. 


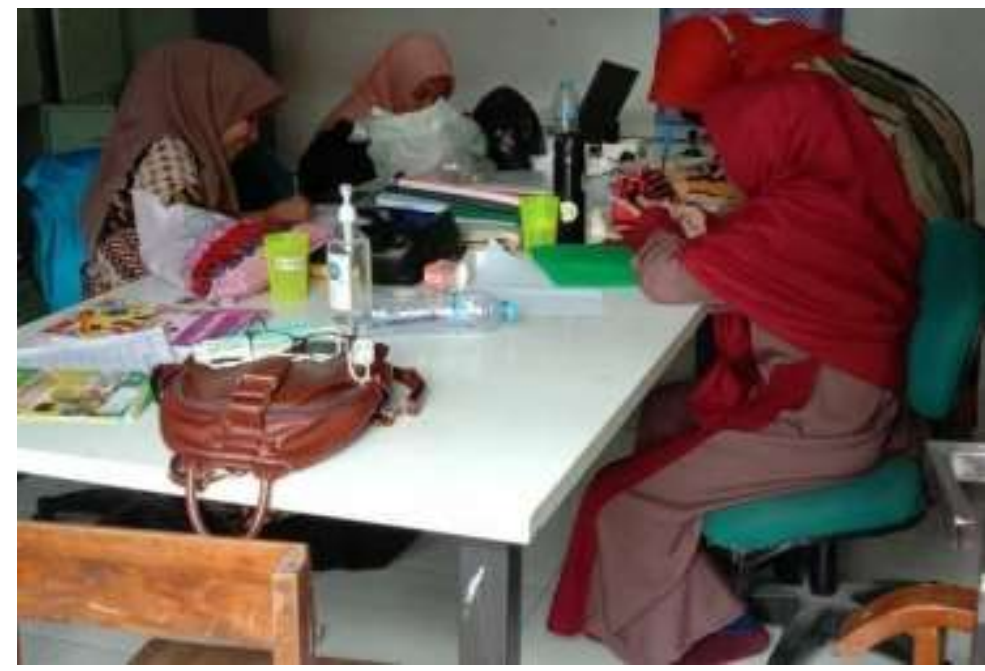

Gambar 2. Suasana Post-tes

Adapun Hasil data Postes materi "Membangkitkan Motivasi

Belajar Siswa” dapatdisajikan dan dianalisis sebagai berikut:

Tabel 3.3

Data Hasil Postes Materi “Membangkitkan Motivasi Belajar Siswa"

\begin{tabular}{|c|c|c|c|c|c|c|c|c|c|c|c|c|c|}
\hline \multirow[t]{2}{*}{ NO } & \multirow[t]{2}{*}{ PESERTA } & \multicolumn{10}{|c|}{ Item Postes } & \multirow[t]{2}{*}{$\mathbf{J}$} & \multirow[t]{2}{*}{$\mathbf{R}$} \\
\hline & & 1 & 2 & 3 & 4 & 5 & 6 & 7 & 8 & 9 & 10 & & \\
\hline 1 & Peserta 1 & 3 & 3 & 3 & 3 & 3 & 3 & 3 & 3 & 3 & 3 & 30 & 3,0 \\
\hline 2 & Peserta 2 & 3 & 3 & 3 & 3 & 3 & 3 & 3 & 3 & 3 & 3 & 30 & 3,0 \\
\hline 3 & Peserta 3 & 4 & 4 & 4 & 4 & 4 & 4 & 4 & 4 & 4 & 4 & 40 & 4,0 \\
\hline 4 & Peserta 4 & 2 & 2 & 2 & 2 & 3 & 2 & 2 & 2 & 2 & 2 & 21 & 2,1 \\
\hline 5 & Peserta 5 & 3 & 3 & 3 & 3 & 3 & 3 & 3 & 3 & 3 & 2 & 29 & 2,9 \\
\hline 6 & Peserta 6 & 3 & 2 & 2 & 2 & 2 & 2 & 3 & 3 & 2 & 3 & 24 & 2,4 \\
\hline 7 & Peserta 7 & 3 & 2 & 2 & 2 & 3 & 3 & 3 & 3 & 3 & 3 & 27 & 2,7 \\
\hline 8 & Peserta 8 & 2 & 2 & 2 & 2 & 2 & 2 & 2 & 2 & 2 & 2 & 20 & 2,0 \\
\hline 9 & Peserta 9 & 3 & 3 & 3 & 3 & 4 & 4 & 4 & 3 & 4 & 4 & 35 & 3,5 \\
\hline 10 & Peserta 10 & 2 & 2 & 3 & 3 & 4 & 4 & 4 & 4 & 4 & 4 & 34 & 3,4 \\
\hline 11 & Peserta 11 & 2 & 2 & 3 & 3 & 4 & 4 & 4 & 4 & 4 & 4 & 34 & 3,4 \\
\hline 12 & Peserta 12 & 2 & 2 & 2 & 2 & 2 & 2 & 2 & 2 & 2 & 2 & 20 & 2,0 \\
\hline 13 & Peserta 13 & 2 & 2 & 2 & 2 & 2 & 2 & 2 & 2 & 2 & 2 & 20 & 2,0 \\
\hline
\end{tabular}




\begin{tabular}{|l|l|l|l|l|l|l|l|l|l|l|l|l|l|}
\hline 14 & Peserta 14 & 2 & 2 & 2 & 2 & 4 & 2 & 2 & 2 & 2 & 2 & $\mathbf{2 4}$ & $\mathbf{2 , 4}$ \\
\hline $\mathbf{1 5}$ & Peserta 15 & 2 & 2 & 2 & 2 & 2 & 2 & 2 & 2 & 2 & 2 & $\mathbf{2 0}$ & $\mathbf{2 , 0}$ \\
\hline & & & & & & & & & & & & & $\mathbf{2 , 7}$ \\
\hline
\end{tabular}

Hasil Postes Materi "Membangkitkan Motivasi Belajar Siswa" pada tabel diatasmenunjukkan bahwa nilai rata-rata kemampuan peserta pendampingan adalah 2,7; apabila dikonsutasikan pada kriteria sebagaimana table skor penilaian, maka nilai tersebut berada pada kategori 2,7 Motivasi Belajar Siswa" dapat diketahui terdapat perubahan kemampuan peserta pendampingan dalam membangkitkan motivasi belajar siswa. Hal tersebut dibuktikan olehnilai rata-rata peserta pendampingan yang mengalami peningkatan dari Pretes ke Postes yaitu dari nilai rata-rata 1,6 (Pretes) menjadi 2,7 (Postes)

i. Diskusi Keilmuan

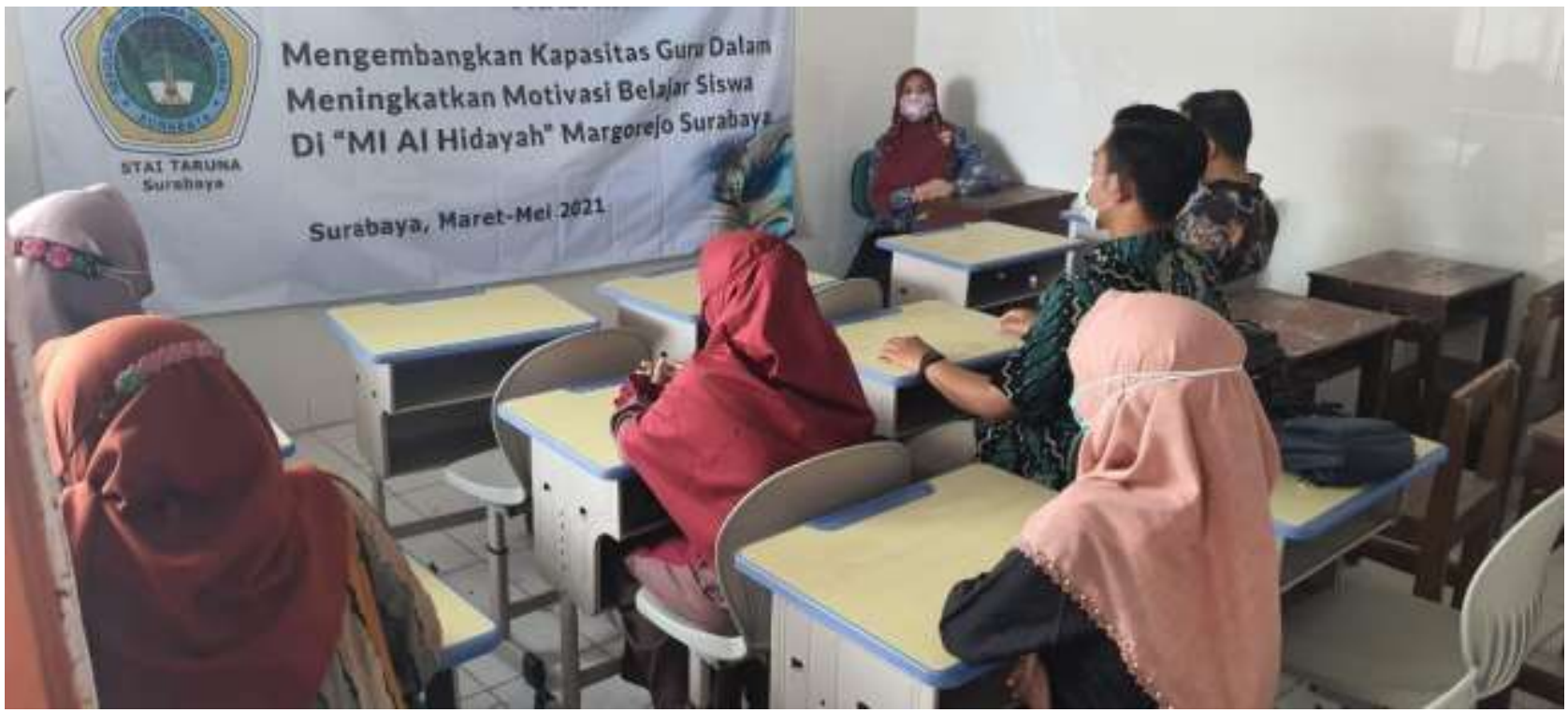

Gambar 3. Suasana Pendampingan

Peningkatan kapasitas bagi seorang guru itu sangat urgen sekali, karena bila kapasitas guru rendah maka akibatnya dalam kegiatan pembelajaran diantaranya: (a) siswa kurang didorong untuk mengembangkan kemampuan berfikir, (b) kegiatan pembelajaran di dalam kelas diarahkan kepada kemampuan anak untuk menghafalkan informasi, (c) otak anak dipaksa untuk mengingat dan menimbun berbagai informasi tanpa dituntut untuk memahami informasi yang diingatnya itu untuk menghubungkannya 
dengan kehidupan sehari-hari. Pembelajaran tidak akan berjalan secara efektif apabila guru tidak bisa mengkondisikan semua komponen pembelajaran dengan baik dan tepat. Dalam konteks ini, peran dan tugas guru dalam interaksi edukatif sangat membantu kelancaran proses pembelajaran. Apalagi dengan adanya inovasi yang dihadirkan guru pada setiap pertemuan. Selain inovasi, guru juga dituntut untuk memiliki kreativitas dalam menjalankan setiap roda pembelajaran. Dari hal inilah akan dicapai tujuan pembelajaran.

Tujuan pembelajaran itu sendiri pada dasarnya bukan hanya mengubah perilaku siswa, melainkan lebih untuk membentuk fondasi karakter dan membentuk sikap mental professional serta berintelektual tinggi yang berorientasi pada global mindset. Untuk itulah diupayakan peningkatan kualitas pembelajaran

Saat ini, peningkatan kualitas pembelajaran menjadi dambaan semua guru. Adanya peran aktif dari seluruh komponen akan mewujudkan pembelajaran yang memang benar-benar bermutu dan juga berkualitas. Kualitas pembelajaran bisa terwujud dan tercapai manakala guru mampu mendongkrak kualitas pembelajaran menjadi meningkat.Peningkatan kualitas pembelajaran dapat dilakukan dengan membangkitkan motivasi belajar di antara siswa.

Dalam kegiatan pembelajaran, peranan dan keberadaan motivasi intrinsik ataupun ekstrinsik sangat dibutuhkan. Karena dengan motivasi ini, siswa dapat mengembangkan aktivitas sekaligus inisiatif mereka.

Aktifitas dan inisiatif ini dapat mengarahkan dan memelihara ketekunan dalam melakukan kegiatan belajar. Tugas utama dari siswa adalah belajar. belajar, belajar, dan terus belajar adalah tugas pokok mereka. Banyak siswa yang mengabaikan tugas pokok tersebut dan menggantinya menjadi tugas sampingan. Banyak dari mereka yang lebih senang bekerja daripada harus belajar. Hal seperti ini apabila dibiarkan, akan merugikan masa depan mereka. Untuk itulah diperlukan beberapa cara untuk menumbuhkan motivasi dalam kegiatan belajar di sekolah agar motivasi mereka tetap terjaga. Hal yang perlu dilakukan adalah dengan memberi angka, memberi hadiah, mengadakan persaingan atau kompetisi, memberi ulangan, dan lain sebagainya. 


\section{j. Memberi Angka}

Angka yang dimaksud di sini adalah symbol atau nilai hasil kegiatan belajar siswa. Angka yang diberikan kepada setiap siswa biasanya bervariasi sesuai dengan hasilyang telah mereka peroleh dari penilaian guru.

Angka merupakan alat motivasi yang cukup memberikan rangsangan kepada siswa untuk mempertahanklan atau lebih meningkatkan prestasi belajar. Angka ini biasanya terdapat dalam rapor sesuai dengan jumlah mata pelajaran yang diprogramkan dalam kurikulum.

Banyak dari siswa yang dengan mengutamakan angka atau nilai yang baik, sehingga yang dikejar adalah nilai ulangan atau nilai-nilai pada rapor. Angka-angka yangbaik itu bagi para siswa merupakan motivasi yang sangat kuat. Tetapi ada juga, bahkan banyak siswa yang belajar dengan keinginan pokok hanya ingin naik kelas. Hal ini menunjukkan motivasi yang dimilikinya kurang berbobot bila dibandingkan dengan siswa yang menginginkan angka yang baik. Walaupun demikian, semua itu harus diingat oleh guru bahwa pencapaian angka-angka seperti itu belum merupakan hasil belajar yangsejati, atau hasil belajar yang bermakna.

Oleh karena itu, langkah selanjutnya yang ditempuh oleh guru adalah bagaimana cara memberikan angka-angka yang dapat dikaitkan dengan value yang terkandung dalam setiap pengetahuan yang diajarkan kepada siswa sehingga tidak sekedar kognitif saja, tetapi juga afektif, dan psikomotornya. Dengan kata lain, ada keseimbangan antara aspek pengetahuan (kognitif), sikap (afektif), dan keterampilan (psikomotor).

k. Memberi hadiah (reward)

Hadiah adalah sesuatu yang diberikan kepada orang lain sebagai penghargaan ataukenang-kenangan atau cendera mata. Hadiah yang diberikan kepada orang lain bisa berupa apa saja, tergantung dari keinginan pemberi atau bisa juga disesuaikan dengan prestasi yang dicapai oleh orang tersebut.

Hadiah yang diberikan guru kepada siswa yang berprestasi berfungsi sebagaibentuk motivasi untuk terus berprestasi. Dengan kata lain, pemberian hadiah tersebut berfungsi sebagai pemacu semangat untuk terus belajar.

1. Persaingan atau Kompetisi

Persaingan atau kompetisi dapat digunakan sebagai alat untuk mendorong motivasi belajar siswa. Baik persaingan individual maupun persaingan 
kelompok, sesungguhnya dapat meningkatkan prestasi belajar siswa dengan catatan bahwa persaingan tersebut dilakukan secara positif dan sehat. Dalam KBM atau dunia pendidikan, kompetisi biasanya diwujudkan dalam bentuk keikutsertaan dalam mengikutiberbagai bentuk perlombaan, seperti cerdas cernat dan olimpiade sains, baik tingkat kota, provinsi, maupun nasional, serta kejuaraan-kejuaraan lainnya. Pemerintah melalui Kementerian Pendidikan terus mengembangkan adanya olimpiade sains nasional (OSN). OSN diadakan setiap tahun dengan melibatkan siswa SMA seluruh Indonesia. Adanya OSN ini mampu mengantarkan generasi kita pada olimpiade sains internasional (OSI)

Oleh karena itu, langkah selanjutnya yang ditempuh oleh guru adalah bagaimana cara memberikan angka-angka yang dapat dikaitkan dengan value yang terkandung dalam setiap pengetahuan yang diajarkan kepada siswa sehingga tidak sekedar kognitif saja, tetapi jua afektif, dan psikomotornya. Dengan kata lain, ada keseimbangan antara aspek pengetahuan (kognitif), sikap (afektif), dan keterampilan (psikomotor).

m. . Ego-involvement

Ego-involvement merupakan salah satu bentuk motivasi yang sangat penting, karena menumbuhkan kesadaran kepada siswa agar merasakan pentingnya tugas dan menerimanya sebagai tantangan, sehingga mereka bekerja keras dengan sebaik-baiknya untuk mengerjakan dan menyelesaikan tugas tersebut. Seseorang akan berusaha dengan segenap tenaga untuk mencapai prestasi yang baik dengan menjaga harga dirinya. Penyelesaian tugas dengan baik adalah symbol kebanggaan dan harga diri, begitu juga untuk siswa sebagai subyek belajar. Para siswa belajar dengan keras bisa jadi karena harga dirinya.

n. Memberi Ulangan

Ulangan adalah salah satu strategi yang penting dalam pengajaran. Melalui ulangan, guru dapat mengetahui sampai di mana dan sejauh mana hasil pengajaran yang telah dilakukannya (evaluai proses) dan sampai sejauh mana tingkat penguasaan siswa terhadap bahan yang telah diberikan dalam rentangan waktu tertentu (evaluasi produk). Dalam kegiatan belajar mengajar, ulangan dapat guru manfaatkan untuk membangkitkan perhatian siswa terhadap bahan pelajaran yang diberikan di kelas.

Ulangan dapat diberikan pada setiap akhir dari kegiatan pengajaran. Agar perhatian siswa terhadap bahan yang akan diberikan dapat bertahan dalam waktu 
yang relative lama, guru sebaiknya memberitahukan kepada siswa bahwa di akhir pelajaran akan diadakan ulangan. Siswa akan menjadi giat belajar kalau mengetahui akan ada ulangan. Oleh karena itu, memberi ulangan ini juga merupakan sarana motivasi. Tetapi yang harus diingat oleh guru adalah jangan terlalu sering (misalnya setiap hari) menyelenggarakan ulangan karena bisa membosankan. Dalam hal ini guru harus juga terbuka, maksudnya kalau akan ulangan harus diberitahukan terlebih dahulu kepada siswa.

o. Mengetahui Hasil

Ingin mengetahui adalah sifat yang sudah melekat di dalam diri setiap orang. Jadi, setiap orang selalu ingin mengetahui sesuatu yang belum diketahuinya. Dorongan ingin mengetahui, membuat seseorang berusaha dengan cara apa pun agar keinginannya itu menjadi kenyataan dan terwujud. Jarak dan waktu, tenaga ataupun materi tidak menjadi soal, yang penting hal-hal yang belum diketahuinya dapat dilihat secara langsung. Dengan mengetahui hasil pekerjaan, apalagi kalau terjadi kemajuan, akan mendorong siswa untuk lebih giat belajar. Semakin ia mengetahui bahwa grafik hasil belajarnya meningkat, maka ada motivasi pada diri siswa untuk terus belajar, dengan suatu harapan hasilnya terus meningkat.

P. Memberi Pujian

Pujian adalah alat motivasi yang positif. Setiap orang senang dipuji. Tak peduli tua atau muda, bahkan anak-anak pun senang dipuji atas suatu pekerjaan yang telah selesai dikerjakannya dengan baik. Orang yang dipuji merasa bangga karena hasil kerjanya mendapt pujian dari orang lain. Kata-kata seperti kerjamu bagus, kerjamu rapi, kerjamu sempurna, selamat sang juara baru, good, excellent, dan sebagainya adalah sejumlah kata-kata yang biasa digunakan orang lain untuk memuji orang-orang tertentu yang dianggap berprestasi.

Dalam kegiatan belajar mengajar, pujian dapat dimanfaatkan sebagai alat motivasi. Karena siswa juga manusia, mereka tentunya juga senang dipuji. Pujian dapat berfungsi untuk mengarahkan kegiatan siswa pada hal-hal yang menunjang tercapainya tujuan pengajaran. Meskipun begitu, pujian harus betul-betul sesuai dengan dengan hasil kerja siswa. Jangan memuji secara berlebihan, karena pujian secara berlebihan akan terkesan sebaliknya. Pujian yang baik adalah pujian yang keluar dari hati seorang guru secara wajar dengan maksud untuk memberikan penghargaan kepada siswa atas jerih payahnya dalam belajar. Misalnya, ada 
siswa yang sukses dan berhasil menyelesaikan tugas dengan baik. Pujian ini adalah bentuk reinforcement yang positif sekaligus merupakan motivasi yang baik serta sebagai penghargaan dari pekerjaan yang diselesaikan dengan baik.

Q. Memberi Hukuman (punishment)

Hukuman adalah reinforcement yang negatif, tetapi tetap diperlukan dalam kegiatan pendidikan. Hukuman yang dimaksud disini tidak seperti hukuman penjara atau hukuman potong tangan, tetapi hukuman yang bersifat mendidik siswa. $^{12}$ Hukuman yang mendidik inilah yang diperlukan dalam dunia pendidikan. Kesalahan siswa karena melanggar disiplin dapat diberikan hukuman berupa sanksi menyapu lantai, mencatat bahan pelajaran yang ketinggalan, atau apa saja yang sifatnya mendidik. Hukuman sebagai reinforcement yang negatif, jika diberikan secara tepat dan bijak bisa menjadi alat motivasi. Oleh karena itu, guru harus memahami prinsip-prinsip pemberian hukuman.

R.Mengembangkan Minat

Minat adalah suatu kecenderungan untuk memberikan perhatian dan bertindak terhadap orang, aktifitas, atau situasi yang menjadi obyek dari minat tersebut dengan disertai perasaan senang. Siswa akan terdorong untuk belajar manakala mereka memiliki minat untuk belajar. Oleh karena itu, mengembangkan minat belajar siswa merupakan salah satu teknik dalam mengembangkan motivasi belajar. Beberapa cara yang dapat dilakukan untuk membangkitkan minat belajar siswa, diantaranya adalah sebagai berikut.

1) Hubungkan bahan pelajaran yang akan diajarkan dengan kebutuhan siswa. Minat siswa akan tumbuh manakala ia dapat menangkap bahwa materi pelajaran itu berguna untuk kehidupannya. Dengan demikian, guru perlu menjelaskan keterkaitan antara materi pelajaran dan kebutuhan siswa.

2) Sesuaikan materi pelajaran dengan tingkat pengalaman dan kemampuan siswa. Materi pelajaran yang terlalu sulit untuk dipelajari atau materi pelajaran yang jauh dari pengalaman siswa, tidak akan diminati oleh mereka. Materi pelajaran yang terlalu sulit tidak akan diikuti dengan baik, sehingga akan menimbulkan kegagalan dalam mencapai hasil yang optimal, dan kegagalan itu dapat membunuh minat siswa untuk belajar. Biasanya minat siswa akan tumbuh kalau ia mendapatkan kesuksusan dalam belajar.

3) Gunakan berbagai model dan strategi pembelajaran secara bervariasi,

\footnotetext{
${ }^{12}$ Nasution, Didaktik Asas-asas Mengajar, (Jakarta: Bumi Aksara, 2010), hlm. 78-82
} 
misalnya diskusi, kerja kelompok, eksperimen, demonstrasi, dan lain-lain.

k. Kerja Sama dan Suasana yang Menyenangkan

Kerja sama merupakan salah satu kunci dalam menumbuhkan kedisiplinan dengan mengingatkan seluruh warga kelas untuk bekerja sama menerapkan halhal yang sudah disepakati bersama. Seorang guru dapat meminta seluruh warga kelas untuk memulai bekerja sama dan bersepakat dalam menerapkan peraturan serta berdisiplin sejak awal tahun ajaran. Untuk melatih kerja sama ini, seorang guru dapat mengajak siswa untuk bermain sambil belajar dengan menggunakan metode pembelajaran yang menggunakan metode kerja sama. Semakin mudah siswa bekerja sama, semakin mudah pula aura kedisiplinan terbentuk. Adapun kerja sama dan suasana yang menyenangkan dapat diwujudkan dengan adanya kerja sama antara guru dan siswa serta antara siswa dengan siswa.

Suasana kelas yang menyenangkan juga sangat menentukan motivasi siswa terhadap materi pelajaran yang ingin disampaikan oleh guru. Suasana menyenangkan ketika proses belajar mengajar dapat diciptkan oleh guru dan siswa. Selain itu, pihak sekolah juga ikut membantu dalam penyediaan ruang kelas yang nyaman dan bersih, sehingga mampu membuat siswa menjadi betah. Kelengkapan sarana dan prasarana yang menunjang kegiatan pembelajaran juga harus disediakan. Apabila memungkinkan, penyediaaan perpustakaan kelas juga perlu diupayakan.

\section{S. Tujuan yang Diakui dan Diterima Baik oleh Siswa}

Segala bentuk motivasi selalu mempunyai tujuan. Apabila tujuan tersebut memiliki arti, pasti siswa akan berusaha untuk mencapainya. Adanya tujuan yang menarik bagi siswa merupakan motivasi yang baik. Motivasi yang baik senantiasa terus dikelola dan dikembangkan. Sebagai guru yang terus mendampingi siswa, sudah seharusnya berusaha agar siswa jelas dalam mengetahui tujuan dari setiap kegiatan pembelajaran, di samping mengetahui kompetensi dasar dan subkompetensi dasarnya.

\section{Kesimpulan}

Dari hasil analisis data diatas dapat disimpulkan sebagai berikut:

1. Mengembangkan kapasitas guru MI Al Hidayah Margorejo Surabaya dilakukan dengan memperhatikan elemen utama dalam pengembangan kapasitas yaitu : a) Membangun pengetahuan, meliputi peningkatan keterampilan, mewadahi 
penelitian dan pengembangan, dan bantuan belajar, b) kepemimpinan, c)Membangun jaringan, meliputi usaha untuk membentuk kerjasama dan aliasnsi, d) Menghargai komunitas dan mengajak komunitas untuk bersama-sama mencapai tujuan, c) Dukungan informasi, meliputi kapasitas untuk mengumpulkan, mengakses dan mengelola informasi yang bermanfaat

2. Membangkitkan motivasi belajar diantara siswa di MI Al Hidayah Margorejo Surabaya dilakukan dengan : a) memberi angka, b) memberi hadiah, c) mengadakan persaingan atau kompetisi, d) ego involvement, e) memberi ulangan, f)mengetahui hasil, g)memberi pujian, h).memberi hukuman, I). mengembangkan minat, j).kerja sama dan suasana yang menyenangkan, h).tujuan yang dialami dan diterima baik oleh siswa 


\section{DAFTAR PUSTAKA}

Aminatul Zahroh, Membangun Kualitas Pembelajaran melalui Dimensi Profesionalisme Guru, (Bandung: Yrama Widya, 2015

Djemari Mardapi, Metodologi Penelitian Kualitatif (Yogyakarta: Lemlit UNY,2007

Djemari Mardabi, Tehnik Penyusunan Instrumen Tes dan Non tes (Yogyakarta: Rosda, 20018)

Lailatu Zahroh, dkk, Mengembangkan Kapasitas Guru dengan Media Pembelajaran ICT,(Surabaya: Jaudar Press, 2016)

M.Dalyono, Psikologi Pendidikan, Cet.I, Jakarta, Rineka Cipta, 2007) Nasution, Didaktik Asas-asas Mengajar, (Jakarta: Bumi Aksara, 2010

Ngalim Purwanto,Psikologi Pendidikan,cet X, (Bandung: Remaja Rosdakarya, 2005)

Riyadi Soeprapto, The Capacity Building for Local Government toward Good Governance (Word Bank, 2010)

Wina Sanjaya, 2006, Strategi Pembelajaran Berorientasi Standar ProsesPendidikan, Jakarta, KencanaPrenada M, hlm 1

Wawancara dengan Bapak HM Djalaluddin, Ketua LP Ma'arif Kota Surabaya pada tanggal 12 Pebruari 2021

Wawancara dengan Bapak Moch. Reza Abady, S.Pd I, Kepala Sekolah MI Al Hidayah Margorejo 